\title{
THE FEDERAL DEPOSIT INSURANCE CORPORATION: REGULATORY FUNCTIONS AND PHILOSOPHY
}

\author{
K. A. RANDALL*
}

The Federal Deposit Insurance Corporation is one of three federal agencies with responsibilities over commercial banks-and the last to be established. It was created in 1933 to help restore public confidence in banks through the provision of insurance coverage for bank deposits and to protect the money supply in banks covered by deposit insurance. ${ }^{1}$ Over the years, the Corporation's regulatory activities and philosophy have developed within its legal framework and in response to changes in banking and in the economy as a whole. In this article, I shall focus on the Corporation's role in bank supervision and on the contributions it has made and can make to the strength and viability of our banking system.

\section{I}

\section{$\because$. The Development of the Federal Bank Supervisory Structure}

The present structure of federal bank supervision reflects its evolution since $186_{3}$ when wartime legislation establishing a national currency was enacted as part of the effort to bring a measure of stability to the monetary system. The early history of banking in the United States was filled with accounts of financial crises and widespread banking failures. ${ }^{2}$ The public was always the principal victim-its liquid resources dissipated and its savings lost.

Almost from the very beginning, federal supervision of banks was directed toward shielding the public from the damage stemming from unsafe and unsound banking practices or from a general weakening of the banking system. Legislation was employed in the attempt to prevent such crises from developing or to soften their impact when they did occur. Both the first and the second Bank of the United States, for example, were established in an effort to introduce some measure of order to the chaotic monetary situation. Both banks, however, proved of limited effectiveness. Their continued existence was opposed by state bank supporters and by both easy-money and hard-money advocates. The second Bank of the United States, in addition, was criticized for its alleged political activities.

* B.S. (Finance and Banking) 1949, M.S. (Econ.) 1958, Brigham Young University. Graduate of the Stonier Graduate School of Banking, r960. Chairman of the Board of Directors, Federal Deposit Insurance Corporation.

${ }^{1}$ Federal Deposit Insurance Act, 12 U.S.C.A. $\$ \S \mathrm{r} 8 \mathrm{II-3I}$ (Supp. 1966). For history of enactment, see note following $\mathrm{I}_{2}$ U.S.C. $\$$ I8II (I964).

${ }^{2}$ For a brief summary of U.S. banking history, see Lester V. ChandeE, The Economics or MoneY AND BaNkING I32-57 (4th ed. I964). 
The National Bank Act of 1864 established the office of the Comptroller of the Currency and set up a system of federally chartered banks. ${ }^{3}$ National banks supervised by the Comptroller were viewed as an answer to the problems created by the multiplicity of state-bank notes in circulation at depreciated value, by the prevalence of bad banks, and by the immediate and urgent need to finance the Civil War.

National-bank notes, backed by government securities, were expected to displace state-bank notes in circulation and provide a more dependable medium of exchange. By restoring public confidence in the circulating medium, it was anticipated that one of the most important elements of instability could be eliminated and the frequency and severity of banking crises thereby significantly reduced. Even when bank deposits began to supplant bank notes as the principal circulating medium, the focus remained unchanged; preservation of the soundness of the banking system and prevention of banking crises were among the principal concerns of the Comptroller of the Currency.

The machinery provided by the National Bank Act to create a sound currency and promote good banks was, nevertheless, still deficient in many respects. Tying the issue of national-bank notes to government obligations did not necessarily provide liquidity to the banking system in times of stress and could also result in poorly timed contractions in the money supply. The supply of eligible government securities was determined by the need for deficit financing and bore no necessary relation to the banking system's demand for liquid assets or to the public's demand for money. Under these circumstances, the money supply could be suddenly absorbed through a shrinkage in government debt outstanding, or it would fail to expand at the appropriate time, thus undermining public confidence in banks and triggering financial panics.

What was needed was an ample and readily available supply of credit, to serve as a backstop to banks experiencing runs on their deposits; otherwise, the pressures that developed whenever the public's confidence in banks was shaken quickly became insupportable. Once a liquidity crisis was underway, it was difficult to repair the damage done to the public's faith in banks. The nature of the problem was recognized quite clearly at the beginning of this century, as the following excerpt from a journal article in rgro by the Director of the United States Mint indicates.

[W] hen a general situation develops and there is a common movement to liquidate, there are no other resources in this country to draw upon and nothing to be done but to sell securities or products or negotiate loans abroad, any of which is a slow and costly process of getting relief in a crisis.

The scattered reserves in local banks are of no avail in a panic. Whether they average five per cent or twenty per cent makes little difference, for the banks that are strong feel none too strong and will hoard every dollar. Gathered into a cen-

${ }^{3}$ Act of June 3, I864, ch. I06, I3 Stat. 99 (codified in scattered sections of I2, I8, I9, 28, 3I U.S.C.), formerly i2 Stat. 655 ( 1863 ). 
tral fund they would aggregate a sum great enough to inspire confidence and could be brought to bear at the point of danger to protect every situation.

The most serious result of this fundamental weakness at the center is the lack of confidence which pervades the whole system and the readiness on the part of thousands of individual banks to take alarm and do, for the purpose of selfprotection, the very thing that precipitates a crisis. ...

The essential thing required to prevent or allay panics is knowledge that there is a central reserve of credit strong enough to provide every solvent bank and business house with ample support. Periods of industrial reaction and of speculative collapse are bound to come occasionally in every country. Private credit is strained at such a time, solvency is put to the test, and the unsound concerns are weeded out. It is of supreme importance at such a time that banks and business houses which are really solvent shall not be broken down and destroyed through inability to obtain the ordinary consideration to which their assets entitle them. There is literally no limit to which disorganization may go unless there is some power strong enough to stay the panic by interposing its undoubted credit to protect the firms and concerns that it finds to be worthy. ....

The establishment of the Federal Reserve System in $1913^{5}$ was designed to fill this need for a centralized pool of funds by creating a lender of last resort. The Federal Reserve Act also set up the beginnings of a modern central bank. But even the resources and powers of the Federal Reserve proved unequal to the task of supporting our banking system under the massive pressures generated by the domestic and international developments which culminated in the Great Depression of the r930s.

The "bank holiday" and suspension of normal banking activities in r933 led to the introduction and passage by Congress of a number of pieces of major legislation affecting banking. The Federal Deposit Insurance Corporation was created in 1933 to reinforce public confidence in the banking system and to safeguard bank deposits through deposit insurance. The Federal Reserve's powers of monetary control and its ability to supply liquidity to member banks were significantly strengthened in the Banking Act of $1935{ }^{\circ}$ As a result, the chances of a recurrence of financial disturbances of the character and magnitude experienced during the Depression were greatly reduced.

The present federal bank supervisory structure has thus evolved largely in response to crisis situations, adjusting and adapting to changing needs. The result may possibly lack organizational precision, reflecting as it does historical accident as well as the diversity of forces that helped to shape its development. The structure enacted by legislation has, nevertheless, demonstrated an impressive ability to change in response to the needs of banking and of the economy.

\footnotetext{
"Roberts, Utilization of Bank Reserves in the United States and Foreign Countries, 36 ANNaLs 523, 532-33 (1910).

Federal Reserve Act, ch. 6, 38 Stat. 251 ( $19 \mathrm{x}_{3}$ ) (codified in scattered sections of 12, 15, 18, 31 U.S.C.).

${ }^{\circ}$ Banking Act of 1935 , ch. $6 \times_{4}, 49$ Stat. 684 (codified in scattered sections of $11,12,15,18,39$ U.S.C.).
} 


\section{The Role of the Federal Supervisory Agencies}

Each of the present federal supervisory agencies was set up to meet particular needs and particular circumstances, creating in the process the present "texture" of bank supervision at the federal level. The Comptroller of the Currency, for example, is the chartering authority for national banks-and the counterpart of the chartering authorities in each of our fifty states. ${ }^{7}$ They are charged with the responsibility for providing adequate banking facilities to serve the convenience and needs of the public. The Comptroller's influence on bank structure, in the case of bank applications to merge, is shared with the Federal Reserve or the Federal Deposit Insurance Corporation. The Federal Reserve's supervisory powers over banks, on the other hand, serve primarily as an adjunct to its conduct of an effective monetary policy.

The Federal Deposit Insurance Corporation exercises supervision over banks from yet another viewpoint-as an insurer of bank deposits. Deposit insurance serves as a stabilizing influence in the economy through its role in strengthening public confidence in banks by protecting funds in deposit accounts. The Corporation accomplishes this objective by standing ready at all times to ensure the safety of the public's bank deposits up to the statutory maximum of insurance provided each depositor. Its supervisory activities are oriented toward the goal of forestalling the development of situations within banking that might threaten public confidence in banks. It also assumes the task of liquidating assets of failed or failing banks that are not "bankable." In the past, the adverse repercussions of individual bank failures or crises tended to "snowball" and spread even to otherwise healthy financial institutions; the Corporation strives to confine the impact to the affected bank alone.

Although the orientation of each supervisory agency necessarily differs from the others because of statutory responsibilities, the overriding consideration in all their activities is-and must be-safeguarding of the public interest. This "public interest" tocus involves not only the fostering of a strong banking system but also a system that will be responsive to the requirements of a dynamic economy. The emphasis is on protection of those who use bank facilities and services; assistance to an individual bank or its management is a necessary incidental consideration. Banks that are potential sources of trouble, for example, receive special attention not only in an effort to prevent failure but for the purpose of minimizing the impact of bank closures on public confidence in the banking system.

\section{III}

The Concept of Deposit Insurance and the FDiC's Insurance Function

A. The History of Deposit Insurance

Against this background, let us take a closer look at the FDIC. The concept of deposit insurance for banks was not a novelty in 1933 when the federal system was

\footnotetext{
The Commonwealth of Puerto Rico and the Virgin Islands are also empowered to charter banks.
} 
established. The proliferation of banks in the period following the demise of the first Bank of the United States in I8II and of the second Bank in 1836 and the subsequent failure of many of these banks resulted in the development of numerous plans to insure bank notes-then the chief means of payment for the business community. The plans that were adopted by several states met with varying degrees of success. The first federal plan came into effect under the National Bank Act, which provided in effect a federal government guarantee for the circulating notes of national banks.

As bank deposits gradually superseded bank notes in importance, plans for deposit guarantees attracted increasing attention. The first legislative proposals for federal guarantee of deposits were introduced in Congress in 1886 . Numerous proposals were also advanced at the state level. In the period from 1907 to $19 \mathrm{I} 7$, eight states sought to protect depositors in one form or another. ${ }^{8}$ The experience of the state funds, however, left much to be desired, partly because the state boundaries afforded too narrow a geographic and economic base for adequate protection.

The federal deposit insurance system was designed to avoid the major shortcomings of the state plans, primarily by making accessible on a nationwide basis sufficient resources to assure a substantial measure of safety and sufficiently comprehensive deposit coverage to be workable. Capital resources of $\$ 289$ million were initially provided by the U.S. Treasury (\$I50 million) and the Federal Reserve Banks (\$r 39 million). By 1948 these funds were repaid out of accumulated revenues, and interest on the use of the funds was paid in full. Since then, a deposit insurance fund-built up from assessments on insured banks and income from investments-has constituted the principal financial backing for the deposit insurance system; the fund totaled $\$ 3,252$ million on December $3 x$, I966. In $x 950$, the FDIC was granted authority to borrow up to $\$ 3$ billion from the Treasury to supplement the fund's resources, ${ }^{0}$ but that power has not been exercised. The deposit insurance program is thus in the final analysis backed also by the support of the taxpayer through the Corporation's ability to borrow from the Treasury.

\section{B. Deposit Insurance Coverage}

Maximum insurance coverage was originally $\$ 2,500$ but was boosted to $\$ 5,000$ in July $1934, \$ 10,000$ in 1950 , and $\$ 15,000$ in October $1966 .^{10}$ Deposit insurance was not designed to provide full protection for all bank deposits. In the first place, the insurance program was set up principally for the benefit of the small depositor who had more limited access to the information considered necessary to reach a decision

\footnotetext{
${ }^{8}$ See History of Legislation for the Guaranty or Insurance of Bank Deposits, in 1950 FDIC ANN. REP. 63.

I2 U.S.C. $\$ 1824$ ( 1964$)$.

10 " $[\mathrm{I}] \mathrm{n}$ determining the amount due to any depositor there shall be added together all deposits in the bank maintained in the same capacity and the same right for his benefit either in his own name or in the names of others except trust funds which shall be insured as provided in subsection (i) of section I8I7 of this title." I2 U.S.C.A. $\$ I_{13}(\mathrm{~m})$ (Supp. $\mathrm{Ig}_{966)}$.
} 
on placement of his funds. It was presumed that the larger deposit holder was better able to evaluate the risks of alternative depository institutions or other investment options. Second, if deposit insurance is considered principally a means of safeguarding the circulating medium, as it was when it was originally introduced, only that portion of deposits maintained as transactions balances would strictly be eligible for coverage. From an administrative standpoint, it is difficult to distinguish between transactions balances and other deposit balances. Moreover, the functional separation of demand deposits and time deposits has become less clear-cut in recent years. The categorization of demand deposits as money-and thus equivalent to transactions balances-and time deposits as near-money loses much of its significance as a growing number of interest-sensitive deposit holders convert demand balances into interestearning time deposits because of attractive rates of return. Third, complete coverage could give bank deposits and other insured accounts (such as share accounts at savings and loan associations) a competitive advantage over other investment outlets in attracting funds. Finally, so-called Ioo per cent insurance tends to have undesirable effects on the private sector-by minimizing the need for the exercise of individual judgment in the placement of deposits and by weakening management incentives to pursue policies most conducive to the protection of deposits.

Despite the weight of arguments against full deposit insurance coverage, it does not follow that coverage should not be increased from time to time. Periodic increases in maximum coverage are justified by a growing economy's need for transactions balances-although the expansion ratio does not necessarily have to be in direct proportion to the rate of economic growth-and may also be called for when the price level rises.

Since its inception, the value and logic of a federal system of deposit insurance-as opposed to insurance systems constituted on a more limited base-have become increasingly clear. Only a national system can provide the broad base-in terms of geographic coverage, numbers of banks, and resources-to assure the needed protection for depositors and a financially self-supporting operation. Widespread participation in the deposit insurance system, in addition, underlines the vital stake that all banks have in the continued strength of the banking system and in the smooth working of the financial mechanisms.

Federal deposit insurance was the precursor of the economic stabilization measures in effect today. It has become an integral part of the government's program designed to promote the goals of economic stability and high employment as set forth in the Employment Act of 1946.11

\section{The Nature of the FDIC Insurance Function}

Deposit insurance provides an essential element of stability in a crucial sector of the economy. Its existence, as noted earlier, helps to preserve public confidence in

\footnotetext{
${ }^{11}$ I5 U.S.C. § I02I (1964).
} 
the solvency of our banking system. The assistance given to distressed and failed banks is important in limiting the adverse repercussions of banks in financial difficulty in affected communities and in protecting the savings of bank depositors. Deposit insurance, furthermore, helps to protect that portion of the nation's money supply in the form of bank deposits. It does not, on the other hand, in and of itself guarantee an efficient banking system, the optimal use of resources (whether of capital or manpower), or the intensity of capital utilization, for example. These are matters within the purview of bank management itself.

Deposit insurance takes effect in a number of different ways. The Corporation can pay off depositors up to the insured limit after a bank has been closed by the chartering authority and placed in receivership. ${ }^{12}$ It can advance funds to facilitate a merger or absorption of a distressed bank by another insured bank in cases where Corporation losses would be minimized. ${ }^{13}$ It can also extend direct assistance to a distressed bank through loans, purchase of assets, or deposit of funds. ${ }^{14}$ Finally, the Corporation has the alternative of organizing and operating "deposit insurance national banks" to provide limited banking services in areas deprived of banking facilities through a bank closure. ${ }^{15}$

From its establishment in 1934 through December $3 \mathrm{I}$, 1966, the Corporation has disbursed a total of $\$ 42 \mathrm{I}$ million. Recoveries from liquidation of assets-realized and anticipated-have amounted to $\$ 373$ million, resulting in net disbursements over the thirty-three-year period of $\$ 48$ million. Depositors in closed insured banks, on the other hand, have been able to recover more than ninety-five per cent of their deposit balances over the same time span.

The insurance functions of the FDIC should not be compared to the insurance functions of a private insurer. Analogies between the two are misleading and incorrect. In the first place, the cost of insurance is not borne directly by the depositorbeneficiary but by the bank holding the deposits. Even more important, however, is the fact that the FDIC does not merely engage to reimburse the depositor for the loss of his deposits but undertakes to minimize bank failures. The Corporation, moreover, is concerned less with keeping the insurance fund intact and more with preserving public confidence in banks. Risk taking for a profit is not a primary motivation in the Corporation's insurance activities. Paramount concern with the broad public interest is the distinguishing feature of the federal deposit insurance system.

Corporation assessments levied on banks consist, in addition, of one rate applied uniformly to the deposit base of each bank and not variable rates somehow related

\footnotetext{
${ }^{12}$ In the event of a receivership of a federally chartered bank or a bank in the District of Columbia, the Corporation must be designated as receiver by the Comptroller of the Currency. The Corporation must act as receiver also of a closed state bank upon request of the state authorities. r2 U.S.C. \$ I82I(c), (e) $(1964)$.

${ }^{13}$ I2 U.S.C. $\$ 1823$ (e) (1964).

14 I2 U.S.C. $\S I_{23}(\mathrm{c})(1964)$. The Corporation was granted this authority in 1950.

${ }^{25}$ I2 U.S.C. $\$ 1821(\mathrm{~h})-(l)(1964)$.
} 
to "risk," although consideration is of course given to banking system losses in the past. The very nature of bank deposit insurance means that the degree of "risk" is not determinate on an actuarial basis. The crucial "public confidence" factor alone points up the difficulty of arriving at any measurable magnitude in determining assessment rates, for example, because it cannot be quantified. The risk to which the insurance fund could be exposed could vary theoretically anywhere upwards from zero, since the degree of risk is a function of the quality of a bank's assets, its capital position, and the caliber of its management. It varies also with the ownership and size configuration of each bank's deposits as well as with changes in the over-all strength of the banking system itself-and, in the final analysis, with changes in the strength of the economy. Weakness in either the banking system or the economy as a whole would make the economy more vulnerable to any loss of public confidence in the safety of its bank deposits. The Corporation's presence is intended primarily to guard against such a lapse of public confidence.

\section{The Relation of Deposit Insurance to Bank Failures}

It might also be worthwhile at this point to emphasize that a deposit insurance system does not seek complete elimination of bank failures. Bank exposure to the forces of the market and testing of an individual bank's judgments in the market place are prerequisites to a strong private-enterprise banking system. Deposit insurance instead attempts to keep bank failures to a minimum and to confine any adverse effects.

Since 1943, there has been a sharp drop in bank failures, due partly to deposit insurance but, in even greater measure, to the economy's recovery from the Great Depression and its greater stability as the objectives of the Employment Act of I946 and related measures were implemented. As a result, the banking system itself is much stronger than it was in the I920s and r93os. An average of fifty-four banks failed each year from 1934 through I942, compared to an average of eighty-two banks a year in the I900-rgrg period, 588 per year in the r920-rg29 period and an annual average of 2,277 from I930 to x933. Since I943, failures have dropped to an average of three each year for insured banks and five for all banks, out of a total of almost I4,00o banks.

Because a weakening of public confidence in the safety of bank deposits cannot be allowed to develop, however, the Corporation considers prevention of bank failure the best safeguard. Financial compensation after a bank closure can never offset fully the damage done. Nevertheless, failures must not be forestalled regardless of cost. Occasionally, for example, mismanagement has seriously damaged a bank's position. In such instances, the closing of a bank by the chartering authorities can be the optimal solution. 


\section{IV \\ The Broad Objectives of FDIC Bank Supervision in the ECONOMY OF THE Ig6OS}

The historical development of federal deposit insurance, its functions, operations, and coverage have been discussed briefly. Now let us look at the over-all objectives of deposit insurance from a supervisory standpoint and at the various channels through which the Corporation accomplishes these objectives.

The over-all objectives can be separated roughly into two broad categories which, for the purposes of this discussion, might be labeled the "static approach" and the "dynamic approach," respectively. The static approach starts with banking as a regulated industry and is oriented toward a strong and vigorous banking system through bank examinations and administration of the law. It is concerned with bank management adherence to the principle of prudence in bank operations and management's adherence to safe and sound banking practices.

The dynamic approach-one that is of increasing importance today-is concerned with the responsibility of federal bank supervisory authorities to assist banks in adjusting to changes in the economic environment. The complexity of the economyboth national and international-and of the financial mechanism makes it difficult for individual institutions to seek and find individual solutions to externally generated problems. This is the sphere in which the Corporation can increase its contribution to banking in the public interest. It can play a useful role in easing the transition period for banks. It can facilitate innovation and adaptation. At the same time, the Corporation itself must maintain a flexible posture to keep up with the constantly changing scene. Developments within banking as well as developments in the domestic economy as a whole, which could have a major impact on banking over the longer run, also must be followed closely.

The Corporation's concern with the adaptability of the banking system to the current economic environment has developed logically from the fundamental changes that have occurred since the Second World War. These changes might be enumerated briefly. In the first place, the U.S. international balance of payments position has become a major factor in the determination of economic policy. Balance of payments considerations have served as a constraint on interest rate policy, for example. They may again become important as a consequence of the sizable foreign purchases of large negotiable certificates of deposit of U.S. banks carrying attractive yields. If the interest differential favoring the United States over major foreign financial centers narrows significantly, both U.S. banks and our payments position could be adversely affected.

Second, the steady expansion of the domestic economy since $196 \mathrm{I}$ to its present high levels poses new problems for banks. Credit demands-both on banks and on 
the money and capital markets-are at record levels, with interest rates to match. Bank liquidity is low. Manpower and plant resources are close to full-employment levels. And each of these developments has been accentuated by the U.S. military effort in Vietnam. As a result, there is less margin for error and less flexibility of action-for banks as well as other sectors of the economy. This condition may persist into the future if economic policy is successful in achieving the goals set forth in the Employment Act of 1946 .

In the banking sector, three major changes might be mentioned. The structure of banking has undergone a transformation of significant proportions. The number of banking offices has increased sharply, while the number of banks has changed little since 1934 because of mergers and consolidation of banking facilities. Banks have also diversified and are providing an ever-expanding range of financial services and a wider variety of deposit facilities.

In addition, banking can no longer be considered a separate and unique industry, except possibly to the extent that it provides demand deposit facilities to the public. Banking today constitutes but one segment of the broad financial market-albeit a major segment. The current shifting of funds between banks and other financial institutions and between financial institutions and the money and capital markets, for example, provides concrete evidence of the interdependence of financial markets. This network of interrelationships cannot be easily compartmentalized or analyzed. The relevant market itself constantly shifts, depending on the observer's focus at any one time. Bank supervisors and bank management consequently can no longer view banks in isolation. They must recognize the possibility of intersectoral flows of funds and be prepared for the widespread repercussions of developments in any single sector of the financial markets on other sectors. The essential unity of the financial markets leads to the conclusion that supervision of financial institutions cannot be limited to only part of the market.

The financial markets have also witnessed some basic changes recently. Of particular interest to the bank supervisory authorities have been the changes in the nature of the savings market. The issuance by banks since $\mathrm{x} 96 \mathrm{r}$ of large-denomination negotiable certificates of deposit to attract the idle balances of corporations has produced essentially a money-market instrument unlike the more traditional passbook savings accounts of individuals. More recently, as business demands for credit have pressed against the limited supply of new savings, new small-denomination savings instruments, such as savings certificates and savings bonds, have been introduced by banks as a means of tapping the funds of the small saver. Some banks are using these savings instruments as an important source of funds. But reliance on either these relatively new deposit instruments or the large negotiable certificate of deposit could create difficulties for banks in periods when money and capital markets are exceedingly tight and bank liquidity has generally declined. 
$\mathrm{V}$

The Channeis of Bank Supervision

The Corporation exercises its supervisory powers through a number of channels. There is the day-to-day administration of the basic statutes and the regulations of the FDIC and their enforcement. Applications for deposit insurance from statechartered banks not members of the Federal Reserve System are considered, and coverage is denied whenever the applicant bank fails to meet the Corporation's standards for admission to insurance. (Federally chartered banks and state-chartered banks that are members of the Federal Reserve System are automatically granted insurance coverage.) The Corporation also processes applications from insured nonmember banks for new branches, change of location of banking offices, and mergers. It may terminate insurance coverage for banks persisting in unsafe and unsound practices, although the bank's depositors continue to be insured for two years after insurance is withdrawn. ${ }^{16}$ Recently, it has been granted the authority to issue cease-and-desist orders. ${ }^{17}$ It can assess penalties for noncompliance of banks with FDIC interest rate regulations. ${ }^{18}$ And it can promulgate regulations relating to all matters under its jurisdiction.

\section{A. Current Issues in Distressed Bank Cases}

Even in the process of carrying out some of the Corporation's routine responsibilities in administering deposit insurance, new issues and hitherto unimportant facets may emerge from old problems and stimulate the development of new approaches. The Corporation, for example, paid off depositors or otherwise provided financial assistance to 464 banks from 1934 to 1965 . Most of these cases presented no unusual problems. But in a rapidly changing environment, such as the one in which we find ourselves today, tried and true methods and guidelines for dealing with failed banks may no longer be sufficient. For example, the FDIC's relationship and obligations to the management and the stockholders of a distressed bank as distinguished from the depositors-where management is largely divorced from ownership-may be in need of clarification. A review of the definition of insolvency and its applicability under current conditions might be undertaken, and consideration might be given as well to some added flexibility in Corporation operations depending on the size of the bank involved. The available channels through which financial assistance could be extended to distressed banks, in addition, might be usefully re-examined. Past experience furnishes some guidance, but it is a fact that the dimensions of the problems have

\footnotetext{
${ }^{16} 12$ U.S.C.A. $\$$ I818(a) (Supp. I966). Section 1818 (a) proceedings for termination of insurance are provided for in cases where an insured bank or its directors or trustees persist in engaging in unsafe or unsound practices in conducting bank business or knowingly or negligently permits its officers or agents to violate applicable banking laws and regulations, after notification of the supervisory agency involved and allowance of a reasonable time period for correction.

${ }^{17}$ I2 U.S.C.A. $\$$ I $8 \times 8$ (b) (Supp. 1966).

${ }^{18}$ I2 U.S.C.A. $\$ 1828$ (g) (Supp. I966).
} 
increased with the size of the institution. The federal supervisory authorities must face up to the challenge of issues such as these.

\section{B. Recent Changes in Legislative Authority}

In a number of instances, recent developments have impelled the federal bank supervisory agencies-and the Corporation in particular-to request additional legislative authority to cope with situations that are inadequately covered-if at all-in the basic statutes. Most of these powers have been sought for the purpose of meeting particular problems. Bank supervisory agencies can be effective only if their authority is adequate and their actions appropriate to the conditions prevailing in the financial markets at any time.

For example, the Federal Reserve, the FDIC, and the Federal Home Loan Bank Board were recently granted greater flexibility for a period of one year to differentiate time money by various criteria in setting interest rate ceilings. ${ }^{10}$ These broader powers were designed to prevent a further escalation of interest rates paid on time money as a result of the intense competition among financial intermediaries for savings.

The existence of mismanagement and similar problems in a number of closed bank cases, on the other hand, was responsible for the granting to the same three agencies and the Comptroller of the Currency of the authority to issue cease-and-desist orders to institutions persisting in unsafe and unsound financial practices or for the removal of the institution's officers who were personally dishonest. ${ }^{20}$ Cease-and-desist powers provide a less drastic means of correcting undesirable management practices and of ensuring bank compliance with the provisions of the Federal Deposit Insurance Act than termination of insurance, which was the principal alternative previously available. Closely related in subject matter was the 1964 amendment to the deposit insurance act providing for reports of changes in control of management in insured banks. $^{21}$ These reporting procedures were instituted to permit closer surveillance by the Corporation of management, which could use various methods to fleece a bank of its liquid assets.

On several occasions, Congress or others interested in banking problems have initiated legislation affecting banking. Only two recent major pieces of legislation are noted for illustrative purposes. The first was the amendment of the Bank Merger Act in $1966^{22}$ which was intended to clarify the application of the competitive criteria involved in bank mergers, their judicial interpretation for banking, and the relevance of antitrust legislation in this area. The second example is the Securities Acts Amendments of $\mathrm{rg64}$, which set up disclosure requirements for publicly owned

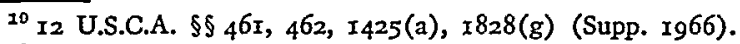

${ }^{20}$ I2 U.S.C.A. $\$ \$ 18$ I 8 (b)-(n) (Supp. I966).

21 I2 U.S.C. $\$$ I $8 \mathrm{I}_{7}(\mathrm{j})(1964)$.

22 I2 U.S.C.A. $\$ 1828$ (c) (Supp. 1966).
} 
banks above a certain deposit size and with more than a specified minimum number of stockholders. ${ }^{23}$ These amendments modified the depositor-oriented character of most existing banking legislation and shifted part of the focus to protection of the shareholder in a bank. Administrative responsibility was delegated to the three federal bank supervisory agencies. The disclosure regulations, as they are called, were an innovation in the banking field. Their impact and implications for the supervisory agencies and for the banking industry will only be realized with the passage of time.

\section{Bank Examination}

Bank visitations by examiners from the bank supervisory agencies are another important avenue through which bank supervision operates. The supervisory authorities must be informed of the condition of operating banks under their respective jurisdictions so that they can assure compliance with existing laws and regulations and prescribe any measures necessary for an efficient and healthy banking institution. This information is essential also to enable bank supervisors to reach decisions on the need for additional banking facilities. Constant surveillance must further be maintained in order to detect individual instances of undesirable banking practices or malfeasance before they threaten depositor confidence in banks.

The FDIC-in addition to the state chartering authorities-examines insured state banks not members of the Federal Reserve System, totaling some 7,300 commercial banks at the present time and 330 mutual savings banks. National banks are examined by the Comptroller of the Currency, and state banks that are members of the Federal Reserve System are examined by the Federal Reserve as well as their respective state authorities. As insurer of deposits, the Corporation has access to the reports of the other supervisory agencies on insured banks and the right to examine these banks if deemed necessary for insurance purposes.

The right of a bank chartering agency to examine banks under its jurisdiction has never been questioned. An insuring agency also must have the right to examine the institutions it is insuring-to evaluate the extent of its risk and to exercise its right to reject those institutions carrying an excessive degree of risk. This right is an essential prerogative of any insurer. It is essential to the FDIC in view of its broad responsibilities for maintaining public confidence in the banking system through deposit insurance.

The process of bank examination permits the supervisory agencies to take a critical look at the operations of the institutions under their jurisdiction. The field examiners ascertain the amount and character of the bank's liabilities, the nature and extent of its assets, and the amount of net sound capital. Bank visitations also provide an excellent opportunity for a useful exchange of views between the supervisory authorities and the bank under examination, ranging from discussions of operational prob-

\footnotetext{
${ }^{23}$ I5 U.S.C. $\$ 78 l(\mathrm{i})(1964)$.
} 
lems and the practices and procedures of the bank to assessments of the impact of current economic developments on banking.

Bank examinations, however, do not-and should not-lead to detailed supervision of the policies of insured banks or to the substitution of supervisory judgments for the decisions of bank management. The commercial banking system must at all times be accorded the freedom to exercise initiative in managing its portfolio and determining its liability structure-as long as its policies and practices are consistent with the public's interest in a strong banking system. The FDIC does not become involved in matters concerned with management of a bank, unless trouble is brewing.

Among the current problems encountered by bank examiners, for example, is a decline in the traditional liquidity ratios of banks. Evaluation of the implications of this development properly comes within the purview of the examiner. There is evidence to indicate that liquidity requirements today may be changing in both character and magnitude, and that liquidity concepts will continue to evolve as the environment alters. ${ }^{24}$

\section{Data Gathering and Analysis}

The periodic reports of condition required of banks by their supervisory authorities supply facts that provide the basis for additional insights into banking conditions in the intervals between bank visits. These reports are supplemented by other continuing reports from banks and by special reports designed to meet special needs.

The data gathering process and subsequent analysis of the information can be an important tool for the supervisory authorities. But the slowness with which such data have become available in the past has been a major obstacle. By the time the data have been compiled and analyzed, major changes have often taken place, and the statistics become principally of historical and academic interest. Past experience is not without value, but during periods of rapid change when new elements are constantly being injected into the economic scene-the kind of situation facing us today-the value of historical data rapidly diminishes with the passage of time.

\section{The "Information Revolution"}

The introduction of automation and computerization into banking within the past few years promises to revolutionize the availability of information-for both banks and bank supervisory authorities. Initially, automation enables a bank to bring its routine bookkeeping and housekeeping chores within manageable proportions. Once this job is completed, the computer can be assigned to more sophisticated management uses-to analyze costs, markets, and other strategic variables in bank operations. Similarly, bank supervisory agencies are taking advantage of computer techniques to assemble and analyze the mass of banking data that has been

\footnotetext{
${ }^{\text {24 }}$ A discussion of liquidity concepts may be found in Pierce, Commercial Bank Liquidity, 52 FED. Reserve BuLl. I093 (1966).
} 
collected over the years and thus to develop new methods of utilizing current information.

The "information revolution" should make a major contribution to upgrading the quality of bank supervision as well as improving the quality of an individual bank's operations. The individual financial institution would be in a better position to maximize the employment of its resources if it were able to marshal easily the statistics generated within the organization itself in a readily understandable and timely format. As significant data for individual institutions are collected by means of a comprehensive management information system and analyzed, comparative data can be made available to each bank to enable it to isolate the relevant variables in its own operations.

The "information revolution" would also help to solve some of the problems stemming from the complexities of our bank supervisory structure. In certain areas of bank supervision-such as bank mergers and new bank and branch applications -either the relevant data have been too voluminous and unwieldy to handle manually or the conceptual base has been poorly adapted for analytical use in such cases. Nevertheless, the various bank supervisory agencies were forced for the lack of an alternative to rely on these data despite their shortcomings and despite the lack of adequate knowledge of their suitability for the problem at hand. The attempt to define the geographic and economic boundaries of bank markets provides an excellent case in point. ${ }^{25}$

Much of this lack of precision and of depth in analysis can be eliminated by the development and use of new, more comprehensive techniques of compilation and analysis. This "information revolution" can provide all the supervisory agencies with current information in the forms best suited for the purpose-and each agency would be working with essentially the same data. The problems and conflicts that arise between supervisory agencies in this area could be greatly reduced in consequence. Attainment of this goal lies in the future, but the tools are now at hand with which to make a start.

\section{An FDIC Project to Assist Banks}

The Corporation also is contemplating, or has under way, a number of projects utilizing the mass of available banking data and some of the new techniques. One vital area deserving closer study is the structure of the banking industry and of the individual bank, for example. A better understanding of the factors influencing a

\footnotetext{
${ }^{25}$ In United States v. Manufacturers Hanover Trust Co., 240 F. Supp. 867 (S.D.N.Y. x965), the federal district court judge drew the line between national and local banking markets by allocating to national markets those customers with demand deposit balances of $\$ 100,000$ or more. On the other hand, a study conducted at the Corporation using FDIC data on size of accounts indicated that the dividing line between "local" competition for demand deposits of individuals, partnerships, and corporations and nationwide markets might be more appropriately drawn between accounts of $\$ 10,000$ or less and accounts of more than $\$ 10,000$. See Mitchell, New Yardsticks in Measuring Bank Competition for Demand Deposits, Bankers Magazine, Summer 1966, at 36 .
} 
bank's structure-such as quantitative relationships, reactions to external stimuli and regulatory actions, and the crucial variables-is our aim.

Consequently, the Corporation has recently authorized a major study of bank operating costs, which we hope will open up new horizons for bank management and bank supervisors. This follows a pilot study that explored data problems and alternative analytical and statistical approaches and suggested the need for investigation in much greater depth. For a number of purposes, statistics currently being collected are worthwhile and useful, but for the analysis of bank costs and bank structure these data reveal some important defects. Accordingly, an effort is being made to develop more meaningful measures of variables that determine bank costs. The emphasis is not along the lines of traditional functional-cost analysis but rather an attempt by means of statistical analysis to isolate cost-determining factors. When the study is finished, we hope to have a more accurate picture of bank costs and of the factors responsible for their size and variation.

The results will be disseminated to banks and may enable them to exercise a greater measure of control over costs than has heretofore been possible and to isolate those factors responsible for differences between their costs and the costs of other banks in the same size group and operating in similar markets. Bank supervisors in turn would be in a stronger position to evaluate the impact of supervisory actions and economic developments on individual banks and on the banking system as a whole.

The need for studies along these lines is supported by evidence that banks have not been making maximum use of their financial resources. The development of the federal funds market, for example, points up the extent to which the reserves of the banking system as a whole can be more fully and efficiently employed, while the adoption of automated check processing systems has demonstrated that significant savings can be achieved in this area of bank operations.

The bank-cost study is but one of the projects to which the Corporation is devoting its energies and resources. Other areas of interest to the Corporation include banking markets, the cost of bank capital, relationships between banks and other financial institutions, and the development of training aids for bank supervision and bank management. ${ }^{26}$

\section{Conclusion}

The principal concern of the supervisory authorities is the strength and viability of the banking system. Consequently, the Federal Deposit Insurance Corporation plays a major role in assisting banks during transition periods and in facilitating their adaptation to economic conditions and to institutional changes. Because the tempo

${ }^{20}$ Committee on Financial Institutions, Report to the President of the United States (ig63), stated, for example, that "the issues pertaining to industrial organization, performance, and market structure among financial institutions have received little systematic study." Id. at 48 . 
of change has been rising and economic and financial interrelationships have become much more complex, this responsibility monopolizes an increasing proportion of our time and energies. By taking full advantage of the "information revolution" currently under way, however, our task may be facilitated and our solutions based more firmly on a strong factual and analytical base. All bank supervisors will benefit from these developments. 